\title{
Calorie Restriction and Moderate-Intensity Continuous Exercise Decrease Free Fatty Acid Levels and Visceral Fat Weight on High Calorie Diet Female Mice
}

\author{
Ahmad Rukhani Lutfi ${ }^{1}$, Lilik Herawati ${ }^{2}$, Widjiati ${ }^{3}$, Gadis Meinar Sari ${ }^{2}$ \\ ${ }^{I}$ Master, Sports Health Science, Faculty of Medicine Airlangga University, ${ }^{2}$ Lecturer, Department of Physiology, \\ Faculty of Medicine Airlangga University, ${ }^{3}$ Professor, Faculty of Veterinary Medicine, Airlangga University
}

\begin{abstract}
Objective: This study aimed to analyze the effect of a combination of calorie restriction and moderateintensity continuous exercise on FFA levels and visceral fat weight in female mice exposed to a high-calorie diet.

Material and Method: This research was randomized posttest used only control group design with female mice as the sampl Balb/c mice (Mus musculus), 8 weeks old, 20-30 grams. It was randomly divided into four groups, namely $\mathrm{C}$ (control group), $\mathrm{G}_{1}$ (moderate-intensity continuous exercise group), $\mathrm{G}_{2}$ (calorie restriction group), and $\mathrm{G}_{3}$ (combination group calorie restriction and moderate-intensity continuous exercise) where in every group consisted six female mice. Providing a high-calorie diet using ad libitum plus D40 as much as $3-5 \%$ of calories $(0.0325 \mathrm{~mL} / \mathrm{gBB})$ for 4 weeks. The provision of a high-calorie diet was done using the sonde technique. Calorie restriction was done $3 x /$ week in 4 weeks by limiting calorie intake to $50 \%$ of standard foods. The moderate-intensity continuous exercise was carried out by swimming for 15 minutes plus $6 \%$ gBB loading, it was done 3 times/week for 4 weeks. The measurement of cholesterol, visceral fat weight, and FFA level was done at the end of treatments.
\end{abstract}

Results: The results found that the mean of cholesterol of C C (171.00 $\pm 47.74 \mathrm{mg} / \mathrm{dL}), \mathrm{G}_{1}(126.00 \pm 15.92 \mathrm{mg} /$ $\mathrm{dL}), \mathrm{G}_{2}(131.50 \pm 22.37 \mathrm{mg} / \mathrm{dL}), \mathrm{G}_{3}(121.17 \pm 21.23 \mathrm{mg} / \mathrm{dL})$ dan $(\mathrm{p}=0.032)$. The mean weight of visceral fat at $C(0.68 \pm 0.23$ grams $), G_{1}(0.25 \pm 0.08$ grams $), G_{2}(0.28 \pm 0.06$ grams $), G_{3}(0.20 \pm 0.03$ grams $)$ and $(p=0.000)$. The mean FFA levels were at $\mathrm{C}(1511.34 \pm 6.19 \mu \mathrm{mol} / \mathrm{L}), \mathrm{G}_{1}(1419.31 \pm 53.61 \mu \mathrm{mol} / \mathrm{L}), \mathrm{G}_{2}(1458.20 \pm 28.89$ $\mu \mathrm{mol} / \mathrm{L}), \mathrm{G}_{3}(1451.55 \pm 43.77 \mu \mathrm{mol} / \mathrm{L})$ and $(\mathrm{p}=0.004)$.

Conclusion: Based on the results of the study, it could be concluded that the provision of calorie restriction and moderate-intensity continuous exercise significantly reduced cholesterol levels, visceral fat weight, FFA levels and in female mice exposed to a high-calorie diet.

Keywords: Calorie restriction, moderate-intensity continuous exercise, free fatty acids, visceral fat, cholesterol

\section{Introduction}

The increasing prevalence of overweight and obesity is a global problem, both in developed and developing

\section{Corresponding Author:}

\section{Gadis Meinar Sari}

Lecturer, Department of Physiology, Faculty of

Medicine Airlangga University

Email: gadis-m-s@fk.unair.ac.id countries ${ }^{1}$. The prevalence of overweight and obesity in women is greater than in men ${ }^{2,3}$. In $2016,39 \%$ of the population aged over 18 years or more than 1.9 billion people were overweight and $13 \%$ of the population over 18 years of age or 650 million people were obese ${ }^{4}$. In Indonesia, based on the results of Basic Health Research ${ }^{5}$ the prevalence rate of overweight increases every year with a prevalence rate of $8.6 \%$ in $2007,11.5 \%$ in 2013 , and $13.6 \%$ in 2018 , while the obesity prevalence rate is $10.5 \%$ in $2007,14.8 \%$ in 2013 , and in 2018 to $21.8 \%$. 
This is a serious problem that will threaten the quality of human resources ${ }^{6}$.

Overweight and obesity are conditions of abnormal or excessive fat accumulation in adipose tissue and become one of the main public health problems $7,8,9$. Moreover, overweight and obese can increase the risk of chronic diseases, such as type 2 diabetes mellitus ${ }^{7,10,11}$, coronary heart disease ${ }^{7,12}$, several types of cancer ${ }^{13,14,15,16,17}$, osteoarthritis and musculoskeletal disorders ${ }^{18}$. Overweight and obesity are often associated with multifactorial diseases resulting from lifestyle, unhealthy eating patterns, and lack of physical activity 19. Poor diet and an inactive lifestyle are contributors to increased fat accumulation ${ }^{20}$. Poor diet such as highcalorie consumption in normal subjects is considered to be a major contributor to the increase in body fat accumulation, especially visceral fat, and an impact on weight gain ${ }^{21}$. Body fat is stored in the form of triglycerides (TG) in adipose and liver tissue which are stimulated by blood glucose ${ }^{22}$. When glucose as the main energy source is unable to meet energy needs, body fat deposits, especially TG, will be hydrolyzed into free fatty acids (FFA) and glycerol as an energy source through fat metabolism ${ }^{23}$. FFA is released from adipocytes into the circulation through lipolysis and circulating FFA concentrations can increase in obese subjects due to an increase in adipose tissue mass ${ }^{24}$. The level of FFA concentrations can affect the increase and decrease in insulin resistance ${ }^{25}$. Lifestyle modification is recommended to be one of the foundations in the management of overweight and obesity ${ }^{26}$. Controlling energy intake and energy expenditure is one of the main mechanisms in regulating energy balance ${ }^{26}$.

Calorie restriction occurs when the intake of food as an energy source is reduced and it causes the utilization of energy sources in the body to increase, especially body fat deposits. When the calorie restriction is in the form of fasting, there is a decrease in blood glucose levels which causes a decrease in insulin secretion and an increase in lipolysis ${ }^{27}$. The high lipolysis due to calorie restriction can increase the hydrolysis of TG to FFA and glycerol ${ }^{28}$. Increasing FFA as the main energy source can result in a decrease in body fat accumulation. According to Maughan et al. ${ }^{29}$ weight loss can come from oxidation of the substrate in the body, oxidation of water and loss of water due to the release of glycogen. Besides, physical exercise also has a positive effect in reducing the increased risk of overweight, and obesity by reducing body fat deposits. During physical exercise, there is a decrease in blood glucose which results in a decrease in insulin and stimulates an increase in the hydrolysis of TG to glycerol and FFA as an energy source ${ }^{30}$. Exercise will stimulate an increase in growth hormone $(\mathrm{GH})$ which has a role in metabolism to stimulate fat to become a more dominant source of energy inactivity than glucose ${ }^{31} .30$ minutes of moderate-intensity exercise can increase the production of FFA to be used as an energy source ${ }^{32}$ and have more potential to reduce visceral fat accumulation 33 .

The combination of calorie restriction and moderate-intensity continuous exercise can be used as a non-pharmacological approach to reducing levels of FFA and body fat deposits. However, the effects of calorie restriction combined with moderate-intensity continuous exercise exposed to a high-calorie diet are not well known. Therefore, this study aimed to analyze the effect of a combination of calorie restriction with moderate-intensity continuous exercise on FFA levels and visceral fat weight in female mice exposed to a highcalorie diet. The hypothesis in this study was that there is an effect of a combination of calorie restriction with moderate-intensity continuous exercise on reducing FFA levels and visceral fat weight in female mice exposed to a high-calorie diet.

\section{Materials and Methods}

This research was a true experimental research design with the randomized control group posttest-only design using $24 \mathrm{Balb} / \mathrm{c}$ female mice (Mus musculus), 8 weeks, 20-30 grams and randomly divided into four groups, namely $C\left(n=6\right.$, control group) $G_{1},(n=6$, moderateintensity continuous exercise group), $G_{2}(n=6$, calorie restriction group), and $\mathrm{G}_{3}(\mathrm{n}=6$, combination group calorie restriction and moderate-intensity continuous exercise). The research was conducted at the Embryology Laboratory, Faculty of Veterinary Medicine, Airlangga University. The experimental animals were placed in a room with a temperature of $26 \pm 2{ }^{\circ} \mathrm{C}$ and humidity of $50-60 \%$, moreover the lighting was set to a light-dark cycle with a regulation of 12 hours of light and 12 hours of darkness. Before the treatment begins, the sample was given a swab test to determine the ovulation period and 
the estrous phase as a starting point for providing calorie restriction and moderate-intensity continuous exercise. All of these research procedures had been approved by the Health Research Ethics Committee of the Faculty of Medicine, Airlangga University, Surabaya Number 11/ EC/KEPK/FKUA/2020.

Diet conditioning with ed libitium plus sonde D40. Sonde D40 was offered at a dose of 3-5\% of calories (0.013 gBB) or $0.0325 \mathrm{ml} / \mathrm{gBB}^{34}$. The $\mathrm{D} 40$ solution was given at 10.00 a.m. Calorie restriction was done by limiting calorie intake by $50 \%$ of standard food or by 5 grams of feed/day. Calorie restriction is done $3 x /$ week at night and a high-calorie ed libitium diet and Sonde D40 at noon 7 times/week for 4 weeks. The moderate-intensity continuous exercise was carried out by immersing the mice with a load of $6 \%$ of the bodyweight of the mice tied to the tail rank ${ }^{35}$ for 15 minutes ${ }^{36}$. Swimming training interventions were given 3 times/week for 4 weeks. The intervention was given at 15.00 p.m. Swimming intervention was carried out in a tub with a diameter of $55 \mathrm{~cm}$ and a height of $60 \mathrm{~cm}$ with a water temperature of $25 \pm 1^{\circ} \mathrm{C}$ and a water depth of $50 \pm 1 \mathrm{~cm}$. In groups $\mathrm{C}$ and $\mathrm{G}_{2}$, they were still given time to play with water as far as their feet on the same day and time to minimize the influence of water. Diet restrictions and physical exercises were given on different days.

One $\mathrm{ml}$ of blood was taken from the left ventricle of the mice. The visceral part of the mice was collected 24 hours after the last intervention. Blood was centrifuged for 10 minutes at $3000 \mathrm{rpm}$. The serum was separated, and stored at $-80{ }^{\circ} \mathrm{C}$ for analysis of FFA levels the following day. Measurement of serum FFA levels using Enzyme-Linked Immunosorbent Assay (ELISA) kit (Catalog No: MBS026749; MyBioSource; San Diego, California, USA) with a concentration unit of $\mu \mathrm{mol} / \mathrm{L}$. Measurement of body weight, and visceral fat weight using a digital scale with a scale of $1 \times 10-3 \mathrm{mg}$.

Cholesterol levels were measured using tail blood which was dripped on the Easy Touch GCU system with Easy Touch II Blood Test Strips by Bioptik Technology, Inc. based on ${ }^{37}$.

Visceral fat weight is fat tissue taken in the visceral area of mice and measured using a digital scale with a scale of 1 x 10-3 m.

Statistical analysis used the Statistical Package for Social Science (SPSS) software version 21 (Chicago, IL, USA). The normality test used the Shapiro-Wilk test, while the homogeneity test used the Levene test. The difference test used One way-ANOVA, and continued with the Least Significant Difference (LSD) post hoc test. The linear correlation was used Pearson productmoment model. The data were presented as mean $\pm \mathrm{SD}$ and, the statistical analyzes used a significant level $(p<0.05)$.

\section{Results}

The results of the statistical analysis of the mean body weight in the first week to the final week after giving a combination of calorie restriction, and moderateintensity continuous exercise could be seen in Figure 1.

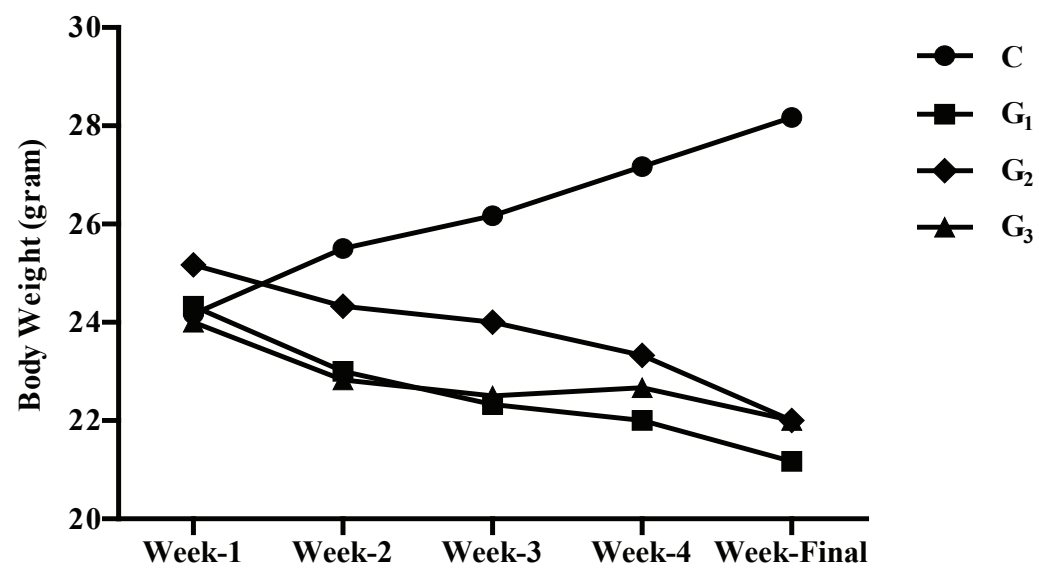

Figure 1. The Mean Body Weight of Mice in Each Group. 
Note: C (control group), $\mathrm{G}_{1}$ (moderate-intensity continuous exercise group), $\mathrm{G}_{2}$ (calorie restriction group), and $\mathrm{G}_{3}$ (combination calorie restriction and moderate-intensity continuous exercise).

Figure 1 showed that there was an increase in mean body weight at the initial week (week-1), and body weight. For the end of the week (week-final) in C, while in $G_{1}, G_{2}$, and $G_{3}$ group, there was a decrease in mean body weight at the end of the week (week-final) compared to body weight in the initial week (week1). The results of the analysis of the mean visceral fat weight could be seen in Table 1 .

Table 1. Result of Statistical Analysis of Mean Visceral Fat Weight

\begin{tabular}{|c|c|c|c|}
\hline Group & $\mathbf{n}$ & Mean \pm SD (gram) & $\begin{array}{c}\text { ANOVA } \\
\text { (p-values) }\end{array}$ \\
\hline C & 6 & $0.68 \pm 0.23$ \\
\hline G1 & 6 & $0.25 \pm 0.08^{*}$ & \multirow{2}{*}{0.000} \\
\hline G2 & 6 & $0.28 \pm 0.06^{*}$ \\
\hline
\end{tabular}

Note: One way-ANOVA, followed by LSD post hoc test, was used to compare the differences among groups. The data were presented as mean $\pm \mathrm{SD}$. * Significant vs control group (C) $(p<0.05)$. C (control group), $\mathrm{G}_{1}$ (moderate-intensity continuous exercise group), $\mathrm{G}_{2}$ (calorie restriction group), and $\mathrm{G}_{3}$ (combination calorie restriction and moderate-intensity continuous exercise group).

Based on Table 1, it proved that the mean visceral fat weight at $C$ is higher than $G_{1}, G_{2}$, and $G_{3}$. The results of the One way-ANOVA analysis exhibited that there was a significant difference in the mean weight of visceral fat in each group $(\mathrm{p}=0.000)$. The results of the LSD post hoc test provided the data that there was a significant difference in the mean weight of visceral fat between $G_{1}$, and $C(p=0.000), G_{2}$ with $C(p=0.000)$, $\mathrm{G}_{3}$, and $\mathrm{C}(\mathrm{p}=0.000)$, while $\mathrm{G}_{1}$, and $\mathrm{G}_{2}(\mathrm{p}=0.671), \mathrm{G}_{1}$ with $G_{3}(p=0.539)$, and $G_{2}$ with $G_{3}(p=0.303)$ did not show a significant difference in mean visceral fat weight ( $p>0.05)$. The results of the analysis of the mean cholesterol levels were apparent in Table 2.

Table 2. Results of Statistical Analysis of Mean Cholesterol Levels.

\begin{tabular}{|c|c|c|c|}
\hline Group & $\mathbf{n}$ & Mean \pm SD $(\mathbf{m g} / \mathbf{d L})$ & ANOVA (p-values) \\
\hline C & 6 & $171.00 \pm 47.74$ & \\
\hline G1 & 6 & $126.00 \pm 15.92^{*}$ & \multirow{2}{*}{0.032} \\
\hline G2 & 6 & $131.50 \pm 22.37^{*}$ & \\
\hline G3 & 6 & $121.17 \pm 21.23^{*}$ & \\
\hline
\end{tabular}


Note: One way-ANOVA, followed by LSD post hoc test, was used to compare the differences among groups. Data were presented as mean $\pm \mathrm{SD}$. $*$ Significant vs control group $(\mathrm{C})(p<0.05)$. C (control group), $\mathrm{G}_{1}$ (moderate-intensity continuous exercise group), $\mathrm{G}_{2}$ (calorie restriction group), and $\mathrm{G}_{3}$ (combination calorie restriction and moderate-intensity continuous exercise group).

Based on Table 2, it showed that the mean cholesterol levels in $\mathrm{C}$ are higher than those of $\mathrm{G}_{1}, \mathrm{G}_{2}$, and $\mathrm{G}_{3}$. The results of the One way-ANOVA analysis proved that there were significant differences in the mean cholesterol levels in each group $(\mathrm{p}=0.032)$. The results of the LSD post hoc test offered the data that there was a significant difference in the mean cholesterol levels between $G_{1}$ and $C(p=0.016), G_{2}$ and $C(p=0.031)$, $\mathrm{G}_{3}$ and $\mathrm{C}(\mathrm{p}=0.008)$, while $\mathrm{G}_{1}$ and $\mathrm{G}_{2}(\mathrm{p}=0.750), \mathrm{G}_{1}$ with $G_{3}(p=0.780)$ and $G_{2}$ with $G_{3}(p=0.551)$ did not show a significant difference in the mean of FFA levels $(p>0.05)$. The results of the analysis of the mean FFA levels were observable in Table 3 .

Table 3. Statistical Analysis Results of Mean FFA Levels.

\begin{tabular}{|c|c|c|c|}
\hline Group & $\mathbf{n}$ & Mean \pm SD $(\boldsymbol{\mu m o l} / \mathbf{L})$ & $\begin{array}{c}\text { ANOVA } \\
(\mathbf{p} \text {-values })\end{array}$ \\
\hline C & 6 & $1511.34 \pm 6.19$ \\
\hline G1 & 6 & $1419.31 \pm 53.61^{*}$ & \multirow{2}{*}{0.004} \\
\hline G2 & 6 & $1458.20 \pm 28.89^{*}$ & \\
\hline
\end{tabular}

Note: One way-ANOVA, followed by LSD post hoc test, was used to compare the differences among groups. Data were presented as mean $\pm \mathrm{SD}$. $*$ Significant vs control group (C) $(p<0.05)$. C (control group), $\mathrm{G}_{1}$ (moderate-intensity continuous exercise group), $\mathrm{G}_{2}$ (calorie restriction group), and $\mathrm{G}_{3}$ (combination calorie restriction and moderate-intensity continuous exercise group).

Based on Table 3 showed that the mean FFA levels in $\mathrm{C}$ were higher than those of $\mathrm{G}_{1}, \mathrm{G}_{2}$ and $\mathrm{G}_{3}$. The results of the One way-ANOVA analysis showed that there were significant differences in the mean FFA levels in each group ( $\mathrm{p}=0.004)$. The results of the LSD post hoc test exhibited that there was a significant difference in the mean FFA levels between $G_{1}$ and $C(p=0.000)$, $\mathrm{G}_{2}$ and $\mathrm{C}(\mathrm{p}=0.024), \mathrm{G}_{3}$ and $\mathrm{C}(\mathrm{p}=0.012)$, while $\mathrm{G}_{1}$ and $\left.\mathrm{G}_{2}(\mathrm{p}=0.089)\right), \mathrm{G}_{1}$ with $\mathrm{G}_{3}(\mathrm{p}=0.153)$ and $\mathrm{G}_{2}$ with $\mathrm{G}_{3}(\mathrm{p}=0.763)$ did not show a significant difference in the mean of FFA levels $(p>0.05)$. The results of the correlation analysis of FFA levels with final body weight and visceral fat weight were shown in Figure 2. 

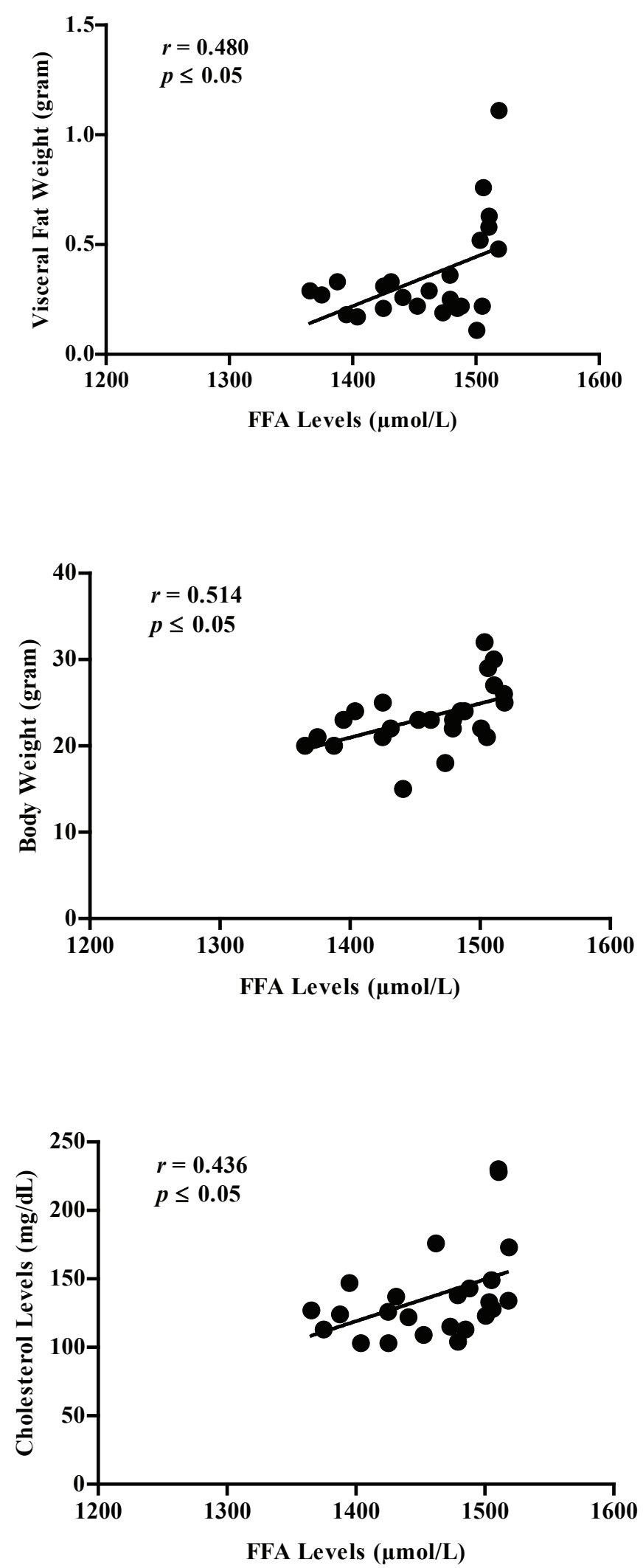

Figure 2. The correlations between FFA levels with visceral fat weight, body weight and cholesterol levels. The significant linear correlation among parameters was visualized in the plot model $(p<0.05)$. Significant with $p<0.05$ by Pearson's product-moment correlation test. 
Based on the results of the study found a significant relationship between FFA levels and final body weight, visceral fat weight and cholesterol levels. The results of the Pearson product-moment linear correlation analysis found that FFA levels were positively correlated with final body weight $(r=0.514, p<0.05)$, visceral fat weight $(r=0.480, p<0.05)$ and cholesterol levels $(r=0.436$, $p<0.05$ ).

\section{Discussion}

Based on the results of the analysis, it had been found that the mean body weight of mice had a difference between before and after treatment ( 4 weeks) and there was a tendency to lose weight in $G_{1}, G_{2}$ and $G_{3}$, while in $\mathrm{C}$ the mean body weight increases (Figure 1). Weight loss in $G_{1}, G_{2}$ and $G_{3}$ is probably due to metabolic factors and the effects of calorie restriction treatment, exercise as well ${ }^{38}$. Calorie restriction and exercise had a positive effect in reducing body fat stores. During calorie restriction and exercise, there was a reduction and decrease in food intake as an energy source which caused the utilization of energy sources in the body to increase, especially body fat deposits. When calorie restriction was in the form of fasting and exercise, there was a decrease in blood glucose levels which caused a decrease in insulin secretion and an increase in lipolysis 27. Increased lipolysis due to calorie restriction could increase the hydrolysis of triglycerides to FFA and glycerol ${ }^{28}$. The increase in FFA as the main source of energy could result in a decrease in body fat stores, thus caused lower body weight of mice in $G_{1}, G_{2}$ and $G_{3}$ compared to $\mathrm{C}$.

Another factor that determined the difference in weight gain and loss was due to appetite stimulation marked by the hormone Ghrelin ${ }^{39}$. Ghrelin is divided into 2 types, namely Acylated Ghrelin (AG) which stimulates appetite and Desacyl Ghrelin (DG) which functions as a trigger for adipogenesis (Mackelvie, 2007). According to King ${ }^{40}$, calorie restriction and exercise lead to appetite suppression that is mediated by AG which is inhibited by $D^{41}$. Emphasis on AG causes no binding on the Growth Hormone Secreting Receptor (GHSR) type 1a with AG, so that appetite stimuli cannot be sent to the hypothalamus and pituitary ${ }^{42}$. Inhibition of appetite stimulation and continuous use of energy during calorie restriction and exercise results in reduced calorie intake and more calorie expenditure, resulting in disturbed energy balance, which causes weight gain in $G_{1}, G_{2}$ and $G_{3}$ to be lower than in C. Conversely, the increase in body weight in $\mathrm{C}$ is higher than that of $\mathrm{G}_{1}, \mathrm{G}_{2}$ and $\mathrm{G}_{3}$ due to an imbalance between calories intake and expenditure. According to Restuastuti ${ }^{43}$ in his research, it is concluded that an imbalance between calories included and calories expended causes weight gain ${ }^{44}$. Likewise, according to Surabhi ${ }^{45}$, the imbalance between calories in and calories out causes excessive accumulation of fat tissue in the body, leading to weight gain ${ }^{38}$. Excess calories are converted into glucose and stored in the liver in the form of glycogen ${ }^{46}$. Glycogen levels in the liver had a certain optimal limit so that if blood glucose levels are sufficient, while glucose intake continues, a mechanism for converting glycogen into fat will be stored in adipose tissue in the form of a fat pad 47. This was why the weight gain in $\mathrm{C}$ is higher than that of $\mathrm{G}_{1}, \mathrm{G}_{2}$ and $\mathrm{G}_{3}$ (Figure 1).

The mean visceral fat weight in $\mathrm{G}_{3}$ was lower than that of $\mathrm{C}, \mathrm{G}_{2}$ and $\mathrm{G}_{3}$ then there was a significant difference in the mean visceral fat weight in each group. These results are in line with the results of previous studies conducted by Verheggen et al. ${ }^{48}$ shows that exercise combined with calorie restriction is the right recommendation in reducing visceral fat weight. This is probably because the combination of calorie restriction and moderateintensity continuous exercise is effective in reducing visceral fat weight. Exercise causes an increase in lean body mass and a decrease in fat mass ${ }^{48}$. Therefore, the combination of calorie restriction and moderate-intensity continuous exercise was an appropriate method to use in reducing visceral fat weight. Calorie restriction could reduce the weight of visceral fat. Likewise, moderateintensity continuous exercise could also cause a decrease in visceral fat weight, so that the combination of calorie restriction and moderate-intensity continuous exercise would be greater in reducing the weight of visceral fat. It was because of the combination of calorie restriction and moderate-intensity continuous exercise which could increase lipolysis of larger fat stores as an energy source. A greater increase in lipolysis could lead to a greater decrease in visceral fat weight.

Moreover, the mean of FFA levels in G1 were lower than those in $\mathrm{C}$. These results are in line with the results of research conducted by $\mathrm{Yu}$ et al. ${ }^{49}$ concluded 
that swimming exercises performed for 8 weeks on Sprague-Dawley Rats significantly reduced FFA levels compared to controls. The decrease in FFA levels in $\mathrm{G}_{1}$ is likely due to the influence of the intervention. During physical exercise, there is a decrease in blood glucose which results in a decrease in insulin and stimulates an increase in the hydrolysis of TG to glycerol and FFA as an energy source ${ }^{30}$. Exercise increases growth hormone $(\mathrm{GH})$, which has a role in metabolism to stimulate fat to become a source of energy used for muscle contraction during exercise ${ }^{31}$, causing the FFA concentration in blood circulation to decrease ${ }^{49}$.

Exercise is an optimal way that can be used to lose weight ${ }^{49}$, improve metabolic health and increase insulin sensitivity ${ }^{50}$. During exercise, triacylglycerol will be hydrolyzed into FFA, then FFA is released into the blood circulation to provide a source of muscle energy during exercise ${ }^{51}$. During intense and intermittent exercise, muscle glycogen particles are broken down, releasing glucose molecules which are then oxidized by muscle cells through anaerobic and aerobic processes to produce adenosine triphosphate (ATP) which is required for muscle contraction during exercise ${ }^{52}$. Exercise performed acutely can increase non-esterified fatty acids in the circulation by increasing sympathetic nerve activity through the release of adrenaline by activating lipase sensitive hormone (HSL) and adipose triglyceride lipase (ATGL) ${ }^{30}$. This lowers blood glucose which will stimulate a decrease in insulin and is associated with greater oxidation of fatty acids and reduced muscle glycogen degradation which can decrease circulating FFA in muscles ${ }^{32}$.

Long-duration exercise can increase fat oxidation as energy production ${ }^{53}$. This is indicated by an increase in blood ketone concentrations, a decrease in insulin concentrations and an increase in lipolysis 54,55,56. The enhanced lipolysis state with reduced lipogenesis theoretically contributes to a decrease in body fat storage. Physical exercise helps reduce waist circumference and visceral fat, lowers blood pressure, increases highdensity lipoprotein (HDL) cholesterol, lowers plasma triglyceride concentrations, and especially promotes an increase in glucose transporter type 4 (GLUT-4) in muscle fiber membranes, improves glucose transport from blood to muscles, which lowers blood glucose ${ }^{57}$. Muscle as a whole is a major contributor to total body glucose and FFA metabolism ${ }^{58}$, individual muscles can contribute differently depending on their fiber composition. Type 1 red muscle fibers are thought to be more sensitive to insulin, with a greater oxidative capacity for glucose and FFA ${ }^{53}$, whereas type II white muscle fibers contain less mitochondria, are considered less sensitive to insulin and contribute less on FFA oxidation $^{59}$.

While the mean of FFA levels in $\mathrm{G}_{2}$ were lower than those in $\mathrm{C}$. These results are in line with the results of research conducted by Kostogrys et al. ${ }^{60}$ concluded that there was a significant difference in FFA levels after caloric restriction (CR) administration compared to controls in mice. The decrease in FFA levels in G2 is likely due to the influence of the intervention. Throughout calorie restriction, the body will respond to energy use by taking fat deposits using the lipolysis method ${ }^{27}$. The increased lipolysis state with reduced lipogenesis theoretically contributes to the decrease in body fat stores ${ }^{51}$. High lipolysis causes TG to be hydrolyzed into glycerol and FFA ${ }^{28}$. FFA is mobilized into the blood circulation as a source of energy during calorie restriction, causing FFA levels to decrease ${ }^{51}$.

Calorie restriction is a calorie restriction that is carried out within a certain time which is useful for reducing body fat deposits ${ }^{61}$ and losing weight ${ }^{50}$. According to Chaouachi et al. ${ }^{62}$, calorie restriction is avoiding eating, drinking and cravings for 11-13 hours. Calorie restriction in Islam is known as fasting which is divided into 2 types, namely compulsory fasting (Ramadan fasting) and sunnah fasting (eg fasting Monday and Thursday. Fasting does not eat or drink for 12-19 hours every day depending on geographic location ${ }^{63}$. Calorie restriction can reduce body weight, cholesterol, low-density lipoprotein (LDL) and triglycerides and increase insulin sensitivity ${ }^{64}$. Physiologically calorie restriction can reduce the function of the digestive organs for 12 hours ${ }^{65}$, Calorie restriction can reduce blood pressure, glucose ${ }^{27}$, leptin and c-reactive protein (CRP) ${ }^{66}$. During caloric restriction, mitochondrial protein increases. In active tissue ${ }^{67}$. Calorie restriction after a high-calorie diet can trigger an increase in mitochondrial sirtuin 3 (SIRT3) transcription, then stimulate antioxidant productivity (SOD and GPX1) and suppress oxidative stress ${ }^{68}$. When in a calorie restriction condition, the body responds to energy use by taking fat deposits using the lipolysis 
method ${ }^{27}$. The increased lipolysis state with reduced lipogenesis theoretically contributes to a decrease in body fat stores ${ }^{51}$.

High lipolysis causes TG to be hydrolyzed into glycerol and FFA ${ }^{28}$. FFA becomes a source of energy and is mobilized to the blood circulation, causing a decrease in FFA ${ }^{51}$. The provision of calorie restriction by fasting can improve the standard of life than the untreated restriction treatment in obese rats and an increase in FFA levels ${ }^{69}$. According to Alvarez-Curto and Milligan ${ }^{24}$ explained that the concentration of FFA circulating in the bloodstream increases in obese subjects due to an increase in the amount of adipose tissue. This is in line with the results of this study which showed that the FFA levels in the control group were higher than the FFA levels in the calorie restriction group.

Based on the results of the study, it showed that the mean FFA levels in $\mathrm{G}_{3}$ were lower than those in $\mathrm{C}$. These results differ from the results of research conducted by Bruss et al. ${ }^{70}$ concluded that giving calorie restriction increased FFA synthesis in mice. The difference in the results of this study may be due to differences in the form of intervention given. In this study, a combination intervention between calorie restriction and exercise was provided, whereas previous studies only provided calorie restriction without exercise. The combination of calorie restriction and exercise causes an increase in energy demand, increasing in the lipolysis process to increase the hydrolysis of TG to FFA and glycerol to meet primary energy needs ${ }^{28}$. Based on the research results of Gopalan et al. ${ }^{50}$ concluded that the combination of calorie restriction and exercise reduces body weight, depots adipose tissue and reduces TG in muscle. A decrease in TG can decrease FFA production. Decreased FFA production can reduce insulin resistance ${ }^{25}$ and lose weight ${ }^{50}$.

The combination of calorie restriction with exercise has been recommended to reduce body weight, improve metabolic health and increase insulin sensitivity and can be used as a non-pharmacological treatment method 50,61 . This is because exercise triacylglycerol will be hydrolyzed into FFA, then FFA is released into the blood circulation to provide a source of muscle energy during exercise ${ }^{51}$. During the provision of calorie restriction with exercise, there is an increase in energy needs, which causes a decrease in blood glucose levels, which causes a decrease in insulin secretion and an increase in lipolysis ${ }^{27}$. Increased lipolysis as a result of calorie restriction intervention with exercise can increase the hydrolysis of TG to FFA and glycerol to meet primary energy needs ${ }^{28}$. When the provision of calorie restriction with exercise is carried out continuously, it can reduce body fat deposits, especially visceral fat, thus causing FFA production to decrease ${ }^{32,33}$.

The combination of calorie restriction with exercise could reduce food intake which affected the production of fatty acids in the body. During exercise, hypoglycemia occurred, which could increase glucagon. When providing calorie restriction with exercise, blood glucose levels decrease which caused a decrease in insulin secretion and an increase in lipolysis ${ }^{27}$. The increased lipolysis state with reduced lipogenesis theoretically contributed to a decrease in body fat stores. High lipolysis causes TG to be hydrolyzed into glycerol and FFA ${ }^{28}$. FFA was used as a source of energy and mobilized to the blood circulation, caused FFA levels to decrease.

\section{Conclusion}

Based on the results of the study, it can be concluded that the provision of calorie restriction and moderateintensity continuous exercise $3 \mathrm{x}$ /week for 4 weeks was effective in reducing serum FFA levels and visceral fat weight in female mice exposed to a high-calorie diet. Further research is needed to reveal further about the mechanism that might be involved such as hormone sensitive lipase (HSL) and adipose triglyceride lipase (ATGL).

Conflict of Interest: The authors declared that there is no conflict of interest.

Acknowledgement: This study was supported by the Fundamental Research Program Ministry of Research, Technology and Higher Education, Indonesia for the research fund.

\section{References}

1. Caballero, B. The Global Epidemic of Obesity: An Overview. Epidemiologic Reviews, 2007;29(1): 1-5, https://doi.org/10.1093/epirev/mxm012.

2. Weiderpass, E., Botteri, E., Longenecker, J.C., 
Alkandari, A., Al-Wotayan, R., Al Duwairi, Q., Tuomilehto, J. The Prevalence of Overweight and Obesity in an Adult Kuwaiti Population in 2014. Front Endocrinol (Lausanne). 2019;9(10): 449. https://doi.org/10.3389/fendo.2019.00449.

3. Chowdhury, R., Ramond, A., O'Keeffe, L.M., Shahzad, S., Kunutsor, S.K., Muka, T., Gregson, J., Willeit, P., Warnakula, S., Khan, H., Chowdhury, S., Gobin, R., Franco, O.H., Di Angelantonio, E. Environmental toxic metal contaminants and risk of cardiovascular disease: systematic review and meta-analysis. BMJ. 2018;29(36)2: k3310. https:// doi.org/10.1136/bmj.k3310.

4. World Health Organization (WHO). Media centre obesity and overweight. Gevena: WHO. 2016.

5. Riset Kesehatan Dasar (Riskesdas). Laporan Nasional Riset Kesehatan Dasar. Jakarta: Kemenkes RI. Available at: http://www.kesmas.kemkes.go.id. 2018.

6. Akter, S., Rahman, M.M., Abe, S.K. and Sultana, P. Prevalence of diabetes and prediabetes and their risk factors among Bangladeshi adults: a nationwide survey. Bulletin of the World Health Organization, 2014;92(3): 204-213A. https://doi.org/10.2471/ BLT.13.128371.

7. Nimptsch, K., Konigorski, S. and Pischon, T. Diagnosis of obesity and use of obesity biomarkers in science and clinical medicine. Metabolism: Clinical and Experimental. 2019;92: 61-70. https:// doi.org/10.1016/j.metabol.2018.12.006.

8. Sudikno, S., Syarief, H., Dwiriani, C.M. and Riyadi, H. Faktor Risiko Obesitas Sentral pada Orang Dewasa Umur 25-65 Tahun di Indonesia (Analisis Data Riset Kesehatan Dasar 2013). The Journal of Nutrition and Food Research, 2015;38(2): 111-120. https://doi.org/10.22435/pgm.v38i2.5540.111-120.

9. World Health Organization (WHO). Obesity and overweight. Gevena: WHO. Available from: http:// www.who.int/mediacentre/factsheets/fs $311 / \mathrm{en} /$. 2015.

10. Broskey, N.T., Obanda, D.N., Burton, J.H., Cefalu, W.T. and Ravussin, E. Skeletal muscle ceramides and daily fat oxidation in obesity and diabetes. Metabolism: Clinical and Experimental, 2018;82: 118-123. https://doi.org/10.1016/j. metabol.2017.12.012.

11. Wang, C., Li, J., Xue, H., Li, Y., Huang, J., Mai, J.,
Chen, J., Cao, J., Wu, X., Guo, D., Yu, L. and Gu, D. Type 2 diabetes mellitus incidence in Chinese: contributions of overweight and obesity. Diabetes Res Clin Pract, 2015;107(3): 424-432. https://doi. org/10.1016/j.diabres.2014.09.059.

12. Koolhaas, C.M., Dhana, K., Schoufour, J.D., Ikram, M.A., Kavousi, M. and Franco, O.H. Impact of physical activity on the association of overweight and obesity with cardiovascular disease: The Rotterdam Study. Eur J Prev Cardiol, 2017;24(9): 934-941. https://doi.org/10.1177/2047487317693952.

13. Chen, Y. Wang, X., Wang, J., Yan, Z. and Luo, J. Excess body weight and the risk of primary liver cancer: An updated meta-analysis of prospective studies. European Journal of Cancer, 2012;48(14): 2137-2145. https://doi.org/10.1016/j. ejca.2012.02.063.

14. Ma, Y., Yang, Y., Wang, F., Zhang, P., Shi, C., Zou, Y. and Qin, H. Obesity and risk of colorectal cancer: a systematic review of prospective studies. PLOS ONE, 2013;8(1): e53916. https://doi.org/10.1371/ journal.pone.0053916.

15. Mackelvie, K.J., Meneilly, G. S., Elahi, D., Wong, A.C.K., Barr, S. I. and Chanoine, J. P. Regulation of Appetite in Lean and Obese Adolescents after Exercise: Role of Acylated and Desacyl Ghrelin. The Journal of Clinical Endocrinology \& Metabolism, 2007;92(2): 648-654. https://doi. org/10.1210/jc.2006-1028.

16. World Cancer Research Fund/American Institute for Cancer Research. Diet, nutrition, physical activity and breast cancer. Continuous Update Project Expert Report 2018. 2018. https://doi. org/10.1007/s12082-007-0105-4.

17. Yang, L., Drake, B.F. and Colditz, G.A. Obesity and Other Cancers. Journal of Clinical Oncology: Official Journal of the American Society of Clinical Oncology, 2016;34(35): 4231-4237. https://doi. org/10.1200/jco.2016.68.4837.

18. Reyes, C., Leyland, K.M., Peat, G., Cooper, C., Arden, N.K. and Prieto-Alhambra, D. Association Between Overweight and Obesity and Risk of Clinically Diagnosed Knee, Hip, and Hand Osteoarthritis: A Population-Based Cohort Study. Arthritis Rheumatol, 2016;68(8): 1869-1875. https://doi.org/10.1002/art.39707.

19. Chooi, Y.C., Ding, C. and Magkos, F. The epidemiology of obesity. Metabolism: Clinical 
and Experimental, 2019;92: 6-10. https://doi. org/10.1016/j.metabol.2018.09.005.

20. Bautista, R.J.H., Mahmoud, A.M., Königsberg, M. and Guerrero, N.E.L.D. Obesity: Pathophysiology, monosodium glutamate-induced model and anti-obesity medicinal plants. Biomedicine \& Pharmacotherapy, 2019;111: 503-516. https://doi. org/10.1016/j.biopha.2018.12.108.

21. Norheim, F. Langleite, T.M., Hjorth, M., Holen, T., Kielland, A., Stadheim, H.K., Gulseth, H.L., Birkeland, K.I., Jensen, J. and Drevon, C.A. The effects of acute and chronic exercise on PGC-1 $\alpha$, irisin and browning of subcutaneous adipose tissue in humans. FEBS Journal, 2014;281(3): 739-749. https://doi.org/10.1111/febs.12619.

22. Hasnain, S.Z., Prins, J.B. and McGuckin, M.A. Oxidative and endoplasmic reticulum stress in $\beta$-cell dysfunction in diabetes. Journal of Molecular Endocrinology, 2016;56(2): R33-R54. https://doi. org/10.1530/JME-15-0232.

23. Arner, P. and Rydén, M. Fatty acids, obesity and insulin resistance. Obesity Facts, 2015;8: 147-155. https://doi.org/10.1159/000381224.

24. Alvarez-Curto, E. and Milligan, G. Metabolism meets immunity: The role of free fatty acid receptors in the immune system. Biochemical Pharmacology, 2016;114: 3-13. https://doi. org/10.1016/j.bcp.2016.03.017.

25. Delarue, J. and Magnan C. Free fatty acids and insulin resistance. Curr Opin Clin Nutr Metab Care, 2007;10(2): 142-148. https://doi.org/10.1097/ MCO.0b013e328042ba90.

26. Gadde, K. M., Martin, C.K., Berthoud, H.R. and Heymsfield, S.B. Obesity: Pathophysiology and Management. Journal of the American College of Cardiology, 2018;71(1): 69-84. https://doi. org/10.1016/j.jacc.2017.11.011.

27. Alfin, R., Busjra, B. and Azzam, R. Pengaruh Puasa Ramadhan terhadap Kadar Gula Darah pada Pasien Diabetes Mellitus Tipe II. Journal of Telenursing (JOTING)， 2019;1(1): 191-204. https://doi. org/10.31539/joting.v1i1.499.

28. Huffman, K.M., Redman, L.M., Landerman, L.R., Pieper, C.F., Stevens, R.D., Muehlbauer, M.J. et al. Caloric Restriction Alters the Metabolic Response to a Mixed-Meal: Results from a Randomized, Controlled Trial. PLoS ONE, 2012;7(4): e28190. https://doi.org/10.1371/journal.pone.0028190.
29. Maughan, R.J., Susan, M. Shirreffs, J.B. Leiper. Errors in Estimation of Hydration Status from Changes in Body Mass. Journal of Sport Sciences, 2007;25(7): 797-804.

30. Polak, J., Bajzova, M. and Stich, V. Effect of exercise on lipolysis in adipose tissue. Future Lipidology, 2008;3(5): 557-572. https://doi. org/10.2217/17460875.3.5.557.

31. Chaves, V.E., Júnior, F.M. and Bertolini, G.L. The metabolic effects of growth hormone in adipose tissue. Endocrine, 2013;44(2): 293-302. https://doi. org/10.1007/s12020-013-9904-3.

32. Karstoft, K., Wallis, G.A., Pedersena, B.K. and Solomon, T.P.J. The effects of interval- vs. continuous exercise on excess post-exercise oxygen consumption and substrate oxidation rates in subjects with type 2 diabetes. Metabolism: Clinical and Experimental, 2016;65(9): 1316-1325. https:// doi.org/10.1016/j.metabol.2016.05.017.

33. Wewege, M., van den Berg, R., Ward, R.E. and Keech, A. The effects of high-intensity interval training vs. moderate-intensity continuous training on body composition in overweight and obese adults: a systematic review and meta-analysis. Obesity Reviews, 2017;18(6): 635-646. https://doi. org/10.1111/obr.12532.

34. Herawati, L. Mekanisme Pengaruh Prekondisi Diet Glukosa Secara Kontinyu-bertahap Terhadap Ekspresi AKT, PDX1, HSP27, Insulin Sel Beta Pankreas Yang Dipapar Diet Tinggi Glukosa. Disertasi. Surabaya: Universitas Airlangga. 2018.

35. Prasetya, R.S., Umijati, S. and Rejeki, P.S. Effect of Moderate Intensity Exercise on Body Weight and Blood Estrogen Level Ovariectomized Mice. Majalah Kedokteran Bandung, 2018;50(3): 47-51. https://doi.org/10.15395/mkb.v50n3.1368.

36. Zhao, D., Sun, Y., Tan, Y., Zhang, Z., Hou, Z., Gao, C., Feng, P., Zhang, X., Yi, W. and Gao, F. Short-duration swimming exercise after myocardial infarction attenuates cardiac dysfunction and regulates mitochondrial quality control in aged mice. Oxidative Medicine and Cellular Longevity, 2018(4079041). https://doi. org/10.1155/2018/4079041.

37. Abdelmotaleb, G., Abdo, M., Abdelmonaem, E., Ahmed, E., \& Aboelsoued, A. Comparative Study Between Measurements of Serum Cholesterol, Uric Acid and Glucose in Children With B-Thalassemia 
By Laboratory and Bedside Methods. International Journal of Advanced Research, 2017;5(6): 963973. https://doi.org/10.21474/ijar01/4498.

38. Kurdanti, W., Suryani, I., Syamsiatun, N.H., Siwi, L.P., Adityanti, M.M., Mustikaningsih, D., Sholihah, K.I. Faktor-faktor yang mempengaruhi kejadian obesitas pada remaja. Jurnal Gizi Klinik Indonesia, 2015;11 (4): 179-190.

39. Littman, A.J., Vitiello, M.V., Schubert, K.F., Ulrich, C.M., Tworoger, S.S., Potter, J.D., Weigle, D.S. and Tiernan, A.M. Sleep, ghrelin, leptin and changes in body weight during a 1-year moderate-intensity physical activity intervention. International Journal of Obesity, 2006;1-10.

40. King, J.A., Wasse, L.K., Stensel, D.J. The Acute Effects of Swimming on Appetite, Food Intake, and Plasma Acylated Ghrelin. Journal of Obesity. 2010;2011: 1-8.

41. Kumar, R., Salehi, S.A., Rehfeld, J.F., Hoglund, P., Lindstrom, E. and Hakanson, R. Proghrelin peptides: Desacyl Ghrelin is a Powerful Inhibitor of Acylated Ghrelin, Likely to Impair Physiological Effects of Acyl Ghrelin but not of Obestatin. A Study of Pancreatic Polypeptide Secretion from Mouse Islets. Regul Pept, 2010;164(2-3): 65-70. https://doi.org/10.1016/j.regpep.2010.06.005.

42. Ozen, S.V., Sonmez. G.T., Bugdayci, G. and Ozen, G. The Effects of Exercise on Food Intake and Hunger: Relationship with Acylated Ghrelin and Leptin. Journal of Sports Science and Medicine. 2011;10(2): 283-291.

43. Restuastuti, T., Jihadi, M., Ernalia, Y. (2016). Hubungan Pola Makan dan Aktivitas Fisik Terhadap Obesitas pada Remaja di SMA Negeri 5 Pekanbaru. Jom FK, 2016;3(1): 1-20.

44. Fan, W. and Evans, R.M. Exercise Mimetics: Impact on Health and Performance. Cell Metabolism, 2017;25(2): 242-247. https://doi.org/10.1016/j. cmet.2016.10.022.

45. Surabhi, R.J. Ghrelin: A Review. Journal of Pharmaceutical Sciences and Research, 2014;6(8): 288-291.

46. Almatsier, S. Prinsip Dasar Ilmu Gizi. Jakarta: PT Gramedia Pustaka Utama. 2009.

47. Merawati, D. Pengantar Ilmu Gizi. Malang: Universitas Negeri Malang (UM PRESS). 2013.

48. Verheggen, R,J.H.M., Maessen, M.F.H. Green, D.J., et al. A Systematic Review And Meta
Analysis On The Effects Of Exercise Training Versus Hypocaloric Diet: Distinct Effects On Body Weight And Visceral Adipose Tissue. Obesity Review, 2016: 1-27.

49. Yu, J., Zheng, J., Liu, X.F., Feng, Z.L., Zhang, X.P., Cao, L.L. and Zhou, Z.P. Exercise improved lipid metabolism and insulin sensitivity in rats fed a high-fat diet by regulating glucose transporter 4 (GLUT4) and musclin expression. Brazilian Journal of Medical and Biological Research, 2016; 49(5): e5129, http://dx.doi.org/10.1590/1414431X20165129.

50. Gopalan, V., Michael, N., Ishino, S., Lee, S.S., Yang, A.Y., Prakash, K.N.B., Yaligar, J., Sadananthan, S.A., Kaneko, M., Zhou, Z., Satomi, Y., Hirayama, M., Kamiguchi, H., Zhu, B., Horiguchi, T., Nishimoto, T. and Velan, S.S. Effect of Exercise and Calorie Restriction on Tissue Acylcarnitines, Tissue Desaturase Indices and Fat Accumulation in Diet-Induced Obese Rats. Scientific Reports, 2016;6: 26445. https://doi.org/10.1038/srep26445.

51. Mika, A., Macaluso, F., Barone, R., Di Felice, V. and Sledzinski, T. Effect of Exercise on Fatty Acid Metabolism and Adipokine Secretion in Adipose Tissue. Front. Physiol, 2019;10:26. https://doi. org/10.3389/fphys.2019.00026.

52. Turner, N., Cooney, G.J., Kraegen, E.W. and Bruce, C.R. Fatty acid metabolism, energy expenditure and insulin resistance in muscle. Journal of Endocrinology, 2014; 220(2): T61-T79. https:// doi.org/10.1530/JOE-13-0397.

53. Volek, J.S., Freidenreicha, D.J., Saenz, C., Kunces, L.J., Creightona, B.C., Bartley, J.M., Davitt, P.M., Munoz, C.X., Andersona, J.M., Maresha, C.M., Lee, E.C., Schuenke, M.D., Aerni, G., Kraemer, W.J. and Phinney, S.D. Metabolic characteristics of keto-adapted ultra-endurance runners. Metabolism: Clinical and Experimental, 2016;65(3): 100-110. https://doi.org/10.1016/j.metabol.2015.10.028.

54. Horowitz, J.F. and Klein S. Lipid metabolism during endurance exercise. Am J Clin Nutr, 2000;72(2): 558S-563S. https://doi.org/10.1093/ ajen/72.2.558S.

55. Lira, F.S., Carnevali Jr, L.C., Zanchi, N.E., Santos, R.V.T., Lavoie, J.M. and Seelaender, M. Exercise intensity modulation of hepatic lipid metabolism. Journal of Nutrition and Metabolism, 2012;(809576): 1-8. https://doi. org/10.1155/2012/809576. 
56. Webster, C.C., Noakes, T.D., Chacko, S.K., Swart, J., Kohn, T.A. and Smith, J.A.H. Gluconeogenesis during endurance exercise in cyclists habituated to a long-term low carbohydrate high-fat diet. Journal of Physiology, 2016;594(15): 4389-4405 https:// doi.org/10.1113/JP271934.

57. Amaral, F., Lima, N.E., Ornelas, E., Simardi, L., Fonseca, F.L. and Maifrino, L.B. Effect of different exercise intensities on the pancreas of animals with metabolic syndrome. Diabetes, metabolic syndrome and obesity : targets and therapy, 2015;8: 115-120. https://doi.org/10.2147/DMSO.S74436.

58. Ng, J.M., Azuma, K., Kelley, C., Pencek, R., Radikova, Z., Laymon, C., Price, J., Goodpaster, B.H., Kelley, D.E. PET imaging reveals distinctive roles for different regional adipose tissue depots in systemic glucose metabolism in nonobese humans. Am J Physiol Endocrinol Metab, 2012;303(9): E1134-E1141. https://doi.org/10.1152/ ajpendo.00282.2012.

59. Pearen, M.A., Eriksson, N.A., Fitzsimmons, R.L., Goode, J.M., Martel, N., Andrikopoulos, S. and Muscat, G.E. The nuclear receptor, Nor-1, markedly increases type II oxidative muscle fibers and resistance to fatigue. Molecular endocrinology (Baltimore, Md.), 2012;26(3): 372-384. https://doi. org/10.1210/me.2011-1274.

60. Kostogrys, R.B., Franczyk-Żarów, M., Manterys, A., Wybrańska, I. Effect of Caloric Restriction on Liver Function in Young and Old APOE/LDLR Mice. Rocz Panstw Zakl Hig, 2018;69(1): 37-43.

61. Dommerholt, M.B., Dionne, D.A., Hutchinson, D.F., Kruit, J.K. and Johnson, J.D. Metabolic effects of short-term caloric restriction in mice with reduced insulin gene dosage. Journal of Endocrinology, 2018;237(1): 59-71. https://doi. org/10.1530/JOE-17-0505.

62. Chaouachi, A., Leiper, J.B., Chtourou, H., Aziz, A.R. and Chamari K. The effects of Ramadan intermittent fasting on athletic performance: recommendations for the maintenance of physical fitness. J Sports Sci, 2012;30(1): S53-S73. https:// doi.org/10.1080/02640414.2012.698297.

63. Khoshdel, A., Kheiri, S., Nasiri, J., Tehran, H. A. and Heidarian, E. The effect of Ramadan fasting on serum leptin, neuropeptide $\mathrm{Y}$ and insulin in pregnant women. Medical journal of the Islamic Republic of Iran, 2014;28(92).

64. Hutchison, A.T., Liu, B., Wood, R.E., Vincent, A.D., Thompson, C.H., O'Callaghan, N.J., Wittert, G.A., Heilbronn, L.K. Effects of Intermittent Versus Continuous Energy Intakes on Insulin Sensitivity and Metabolic Risk in Women with Overweight. Obesity (Silver Spring), 2019;27(1): 50-58. https:// doi.org/10.1002/oby.22345.

65. Cherif, A., Roelands, B., Meeusen, R., Chamari, K. Effects of Intermittent Fasting, Caloric Restriction, and Ramadan Intermittent Fasting on Cognitive Performance at Rest and During Exercise in Adults. Sports Medicine, 2016;46: 35-47. https://doi. org/10.1007/s40279-015-0408-6.

66. Klempel, M.C., Kroeger, C.M., Bhutani, S., Trepanowski, J.F. and Varady, K.A. Intermittent fasting combined with calorie restriction is effective for weight loss and cardio-protection in obese women. Nutrition Journal, 2012;11(98). https://doi. org/10.1186/1475-2891-11-98.

67. Schwer, B., Eckersdorff, M., Li, Y., Silva, J.C., Fermin, D., Kurtev, M.V., Giallourakis, C., Comb, M.J., Alt, F.W. and Lombard, D.B. Calorie restriction alters mitochondrial protein acetylation. Aging Cell, 2009;8(5): 604-606. https://doi. org/10.1111/j.1474-9726.2009.00503.x.

68. Merksamer, P.I., Liu, Y., He, W., Hirschey, M.D., Chen, D. and Verdin, E. The sirtuins, oxidative stress and aging: an emerging link. Aging (Albany NY), 2013;5(3): 144-150. https://doi.org/10.18632/ aging. 100544

69. Vasselli, J.R., Weindruch, R., Heymsfield, S.B., Pi-Sunver, F.X., Boozer, C.N., Yi, N., Wang, C., Pietrobelli, A. and Allison, D.B. Intentional weight loss reduces mortality rate in a rodent model of dietary obesity. Obesity Research, 2005;13(4): 693-702. https://doi.org/10.1038/oby.2005.78.

70. Bruss, M.D., Khambatta, C.F., Ruby, M.A., Aggarwal, I. and Hellerstein, M.K. 2010. Calorie restriction increases fatty acid synthesis and whole body fat oxidation rates. Am J Physiol Endocrinol Metab, 2010;298: E108-E116. https://doi. org/10.1152/ajpendo.00524.2009. 